\title{
Pengaruh Person Job Fit dan Person Organization Fit Terhadap Organizational Citizenship Behavior dan Kinerja Karyawan Universitas Islam Kalimantan Muhammad Arsyad Al Banjari Banjarmasin
}

\author{
Muhammad Alfani ${ }^{1}$, Muhammad Hadini ${ }^{2}$ \\ ${ }^{1,2}$ Dosen Fakultas Ekonomi Uniska MAB Banjarmasin
}

\begin{abstract}
Research done on employees of the University of Islamic Kalimantan Muhammad Arsyad Al Banjari Banjarmasin about person job fit (PJFit) and the person organization fit (POFit) against organization citizenship behavior (OCB) and The employee performance. From a population of 105 employees the University of Islamic Kalimantan Muhammad Arsyad Al Banjari, Banjarmasin, and by using the formula the census, then spread the now to as many as 105 people sample respondents. By using the software AMOS version 20.0 SEM model equations and use, so that research results obtained; The perception of the person job fit has no effect to the OCB and has no effect to the performance of employees. But the perception of the person job fit has effect to OCB and to on employee performance, if applied to the assumption that it is implemented properly in the process of recruitment of the employees in the form of the application of the jobs analysis, of the job description, and the job specification, as well as the assessment of the work or Jobs Evaluation. Furthermore the perception person organization fit significantly to effect the $\mathrm{OCB}$ and employee performance. Perception OCB significantly influential on performance of employees.
\end{abstract}

Keyword ; PJFit, POFit, OCB, and Employee Performance.

Abstrak

Penelitian dilakukan pada karyawan Universitas Islam Kalimantan Muhammad Arsyad Al Banjari Banjarmasin tentang job fit orang (PJFit) dan organisasi person fit (POFit) terhadap organizational citizenship behavior (OCB) dan The employee performance. Dari populasi 105 karyawan Universitas Islam Kalimantan Muhammad Arsyad Al Banjari, Banjarmasin, dan dengan menggunakan rumus sensus, kemudian menyebar sekarang menjadi sebanyak 105 orang responden sampel. Dengan menggunakan software AMOS versi 20.0 persamaan dan penggunaan model SEM, sehingga hasil penelitian yang didapat; Persepsi tentang kecocokan pekerjaan orang tidak berpengaruh pada OCB dan tidak berpengaruh pada kinerja karyawan. Tetapi persepsi tentang kecocokan pekerjaan orang berpengaruh terhadap OCB dan pada kinerja karyawan, jika diterapkan pada asumsi bahwa itu diterapkan dengan benar dalam proses rekrutmen karyawan dalam bentuk aplikasi analisis pekerjaan, pekerjaan deskripsi, dan spesifikasi pekerjaan, serta penilaian pekerjaan atau Evaluasi Pekerjaan. Selanjutnya organisasi orang persepsian sangat sesuai untuk mempengaruhi OCB dan kinerja karyawan. Persepsi OCB berpengaruh signifikan terhadap kinerja karyawan.

Kata kunci : PJFit, POFit, OCB, dan Employee Performance

\section{INTRODUCTION}

Kualitas karyawan merupakan salah satu kunci dalam menentukan perkembangan sebuah organisasi, baik institusi maupun perusahaan. Sebagai penggerak suatu organisasi untuk mencapai tujuan organisasi diperlukan karyawan yang profesional dalam bidangnya, oleh karena itu, suatu organisasi dapat mengalami pertumbuhan dan berkelanjutan tergantung pada Kinerja karyawannya. Kinerja Karyawan merupakan tanggung jawab setiap Perusahaan, mulai dari perekrutan karyawan sampai kepada kepuasan karyawan pada saat melakukan pekerjaan, dan ketika karyawan merasa nyaman dengan pekerjaannya tanpa mempunyai beban berlebihan, maka akan timbul kepuasan yang dirasakan karyawan. Kepuasan tersebut mendorong timbulnya prestasi yang baik bagi perusahaan melalui peningkatan kinerja karyawan sehingga pada saat memberikan pelayanan kepada konsumen akan menjadi lebih baik dan secara timbal baliknya bagi perusahaan adalah peningkatan kinerja yang akan berdampak baik bagi perusahaan tersebut.

Dalam literatur konsep yang mempengaruhi kinerja karyawan antara lain ; Person Job Fit (Edwards, 1991; O'Reilly, Chatman, \& Caldwell, 1991) dan Person Organization Fit, (Kristof, 1996; Netemeyer et al., 1999, Valentine et al., 2002; Vancouver et al., 1994). Selanjutnya berdasarkan kajian empiris, kinerja karyawan dipengaruhi oleh 
Organizational Citizenship behavior (OCB) sebagai intervening variable Dennis Organ (1997), Barnard (dalam Jahangir, Akbar, Haq, 2004), Podsakoff, et al. (2009), yakni ; dalam memilih karyawan dengan nilai dan keyakinan yang sesuai dengan karakteristik pekerjaan dan karakteristik organisasi membentuk pengalaman - pengalaman yang dapat memperkuat kinerja karyawan. Diduga pula langsung maupun tidak langsung melalui intervening variable, organizational citizenship behavior berpengaruh terhadap kinerja karyawan.

\section{Rumusan Masalah}

Berdasarkan latar belakang tersebut, maka dikemukakan permasalahan sebagai berikut :

1. Apakah Person Job Fit berpengaruh Signifikan terhadap Organizational Citizenship Behaviour $(O C B)$ Karyawan Universitas Islam Kalimantan Muhammad Arsyad Al Banjari Banjarmasin?

2. Apakah Person Organization Fit berpengaruh Signifikan terhadap Organizational Citizenship Behaviour (OCB) Karyawan Universitas Islam Kalimantan Muhammad Arsyad Al Banjari Banjarmasin?

3. Apakah Person Job Fit berpengaruh Signifikan terhadap Kinerja Karyawan Universitas Islam Kalimantan Muhammad Arsyad Al Banjari Banjarmasin?

4. Apakah Person Organization Fit berpengaruh Signifikan terhadap Kinerja Karyawan Universitas Islam Kalimantan Muhammad Arsyad Al Banjari Banjarmasin?

5. Apakah Organizational Citizenship Behaviour $(O C B)$ berpengaruh signifikan terhadap Kinerja Karyawan Universitas Islam Kalimantan Muhammad Arsyad Al Banjari Banjarmasin?

\section{LITERATUR REVIEW}

\section{Person Job Fit (P-J Fit)}

Menurut teori person job fit, adanya kesesuaian antara karakteristik tugas/pekerjaan dengan kemampuan individu untuk melaksanakan tugas tersebut, akan memperkuat ikatan karyawan terhadap pekerjaannya, yaitu karyawan akan lebih komitmen terhadap pekerjaan (Allen dan Meyer, 1997 dalam Ozag dan Duguma, 2005). Job Fit mengandung pengertian yaitu kesesuaian tenaga kerja yang dibutuhkan perusahaan.

Studi pada masalah kesesuaian individu dengan pekerjaan, dalam sebuah organisasi telah menjadi pokok bahasan dalam penelitian beberapa waktu yang lalu. Hasil penelitian Sims \& Galen Kroeck (1994:939) menyebutkan bahwa: "It is readily accepted that types of jobs, while this concept may appear obvious, the person-situation match in other aspects of the employment situation is perhaps equally important as the type of work performed". Dan sudah dapat diterima bahwa berbagai jenis individu yang berbeda memiliki kesesuaian pada berbagai jenis pekerjaan yang berbeda pula. Dengan demikian jelaslah bahwa kesesuaian antara individu dengan jenis pekerjaan dalam berbagai aspek lain pada situasi pekerjaan mungkin sama pentingnya dengan jenis pekerjaan yang harus dilakukan. Sehingga akan diperoleh karyawan yang benar-benar memiliki kompetensi yang diinginkan organisasi, yaitu yang mampu untuk berubah mengikuti pekerjaan.

Telah dinyatakan bahwa seseorang akan memilih tempat bekerja yang paling sesuai dengan karakteristik-karakteristik pribadi mereka masingmasing. Dikemukakan oleh Tom sebagaimana dikutip oleh Sims \& Galen (1994:939) "a person's preference for an organization should vary with the degree of similarity between his self-concept and his image of work in the organization". Pilihan seseorang akan suatu perusahaan akan tergantung pada tingkat kemiripan antara konsep pribadi yang ada dalam dirinya dan gambaran yang ia lihat pada pekerjaan di perusahaan tersebut.

Bohlander dan Snell

$(2004: 184)$ mengemukakan, bahwa kesesuaian individu dengan pekerjaan (person-job fit) merupakan proses Job specifications, in particular, help identify the individual competencies employees need for success-the knowledge, skills, abilities, and other factors (KSAOs) that lead to superior performance. Ini berarti, kesesuaian individu-pekerjaan (person job fit) merupakan proses spesifikasi pekerjaan sebagai upaya untuk membantu mengidentifikasikan kompetensi individual karyawan yang dibutuhkan untuk memperoleh kesuksesan, seperti pengetahuan, kemampuan, keahlian dan faktor lain yang dapat mengacu pada pemerolehan kinerja yang superior, oleh karena itu variabel ini sangat penting diperhatikan oleh perusahaan. Demikian juga, Bowen, et. al. (1997:37) menyatakan bahwa kesesuaian individupekerjaan (person job fit) memperhitungkan jenisjenis individu yang diperlukan dengan kualifikasi: kesesuaian knowledge (pengetahuan), skill (keterampilan), abilities (kemampuan), social skills (keterampilan sosial), personal needs (kebutuhan individu), values (nilai-nilai), interest (minat) dan personality traits (sikap individu). Dengan demikian penting bagi perusahaan untuk melakukan penyesuaian individu-pekerjaan sehingga memperoleh kinerja individu yang optimal.

Berdasarkan pendapat Bohlander dan Snell (2004) serta Bowen et.al. (1997) jika disinergikan, maka Person Job Fit mempunyai 8 indikator yaitu : Knowledge, Skill, Abilities, Social skills, Personal needs, Values, Interest, Personality traits. 


\section{Person organization fit}

Person-organization fit (P-O Fit) secara luas diartikan sebagai kesesuaian antara nilai-nilai organisasi dan nilai-nilai individu, (Kristof, 1996; Netemeyer et al., 1999; Vancouver et al., 1994). P$\mathrm{O}$ Fit didasarkan pada asumsi keinginan individu untuk memelihara kesesuaian mereka dengan nilainilai organisasi, (Schneider, Goldstein, \& Smith, 1995). P-O Fit diartikan sebagai kesesuaian antara kepribadian individu dengan karakteristik organisasi, (Bowen et al, 1997). P-O Fit digambarkan sebagai bangunan multidimensional yang terdiri dari tiga jenis yaitu: nilai-nilai, kepribadian, dan lingkungan kerja, Handler (2004). Dalam P-O Fit kesesuaian antara karyawan dengan organisasi sangat ditekankan (Barrick, et.al., 2005).

Menurut Robert L. Mathis dan John H. Jackson (2004:191), definisi dari metode Person Organization Fit adalah: Person Organization Fit is the congruence between individuals and organizational factors. Artinya Kecocokan Individu dengan organisasi adalah penyesuaian antara individu dengan faktor-faktor organisasi perusahaan. Dengan demikian Person Organization Fit adalah suatu metode seleksi yang memperhitungkan kesesuaian antara individu dengan nilai-nilai organisasi, dan suatu teknik yang menempatkan proses seleksi sebagai sarana untuk berinteraksi antara organisasi dengan individu, di mana Kecocokan antara Individu dengan Pekerjaan (Person Job Fit), dan Kecocokan Individu dengan organisasi (Person Organization Fit), diperhitungkan dan didefinisikan dengan sederhana, daripada model seleksi tradisional.

Menurut Bowen, et.al (1997:48) indikatorindikator seleksi dengan metode Person Organization Fit adalah sebagai berikut : Kesesuaian pengetahuan calon karyawan dengan nilai-nilai organisasi, Kesesuaian keterampilan calon karyawan dengan nilai-nilai organisasi, Kesesuaian kemampuan calon karyawan dengan nilai-nilai organisasi, Kesesuaian kebutuhan calon karyawan dengan lingkungan nilai-nilai organisasi, Kesesuaian antara nilai-nilai personal calon karyawan dengan nilai-nilai organisasi.

\section{Organizational Citizenship Behavior (OCB)}

Konsep OCB pertama kali dikemukakan oleh Dennis Organ (1997) dan mendefinisikan OCB sebagai : individual behaviour that is discretionary, not directly or explicitly recognized by the formal reward system, and that in the aggregate prompts the effective functioning of the organization. By discretionary, we mean that the behaviour is not an enforceable requirement of the role or job description, that is the clearly specifiable terms of the person's employment contract with the organization ; the behaviour is rather a matter of personal choice, such that its ommision is not generally understood as punishable.

OCB merupakan perilaku sukarela individu di luar deskripsi pekerjaan yang secara eksplisit atau secara tidak langsung diakui oleh sistem penghargaan formal, dan secara agregat dapat meningkatkan fungsi efektivitas dalam sebuah organisasi. Namun lebih dari setengah abad yang lalu, Barnard (dalam Jahangir, Akbar, Haq, 2004) telah menyatakan konsep serupa dengan OCB, konsep tersebut dinyatakan dengan willingness of individuals to contribute cooperative efforts to the organization was indispensable to effective attainment of organizational goals yaitu : kesediaan individu untuk berkontribusi dengan cara berupaya bekerja sama dengan organisasi sangat diperlukan untuk mencapai tujuan-tujuan organisasi dengan efektif.

Podsakoff, et al. (2009) menyatakan, efek dari OCB tidak hanya dirasakan bagi organisasi melainkan bagi individu yang mencerminkan OCB itu sendiri. Individu yang menampilkan OCB akan cenderung mendapatkan penilaian kinerja yang lebih baik dari pemimpinnya daripada karyawan yang tidak menampilkan OCB. Hal ini dikarenakan karyawan yang menampilkan OCB akan lebih disukai dan dianggap lebih menguntungkan bagi organisasi atau adanya kemungkinan lain seperti pimpinan yang sadar bahwa OCB memainkan peranan penting dalam kesuksesan sebuah organisasi dan menganggap OCB sebagai bentuk dari komitmen seorang karyawan, akan menilai kinerja karyawan yang menampilkan OCB lebih baik daripada yang tidak menampilkan OCB. Selanjutnya penilaian kinerja karyawan yang lebih baik juga sering dikaitkan dengan penghargaan, promosi, kenaikan gaji atau bonus. OCB telah memperlihatkan beberapa dampak positif terhadap kinerja karyawan dan pada akhirnya bermuara pada efektivitas organisasi.

Berdasarkan pendapat Dennis Organ (1997) dan Podsakoff, et.al., (2009) jika disenergikan dapatlah dinyatakan bahwa Organizational Citizenship Behavior (OCB) mempunyai 8 dimensi atau indikator sebagai berikut : Altruism, Courtesy, Sportsmanship, Civic Virtue, Conscientiousness, Organizational compliance, Organizational loyalty, Self development.

\section{Employee Performance}

Kinerja karyawan adalah tingkat hasil kerja karyawan dalam mencapai persyaratan-persyaratan pekerjaan yang diberikan. Kinerja adalah hasil kerja karyawan baik dari segi kualitas maupun kuantitas berdasarkan standar kerja yang telah ditetapkan (Simamora, 2007: 500).

Robbins, S.P. (2007: 145), kinerja adalah suatu ukuran yang mencakup keefektifan dalam 
pencapaian tujuan atau efisiensi yang merupakan rasio dari keluaran efektif, terhadap masukan yang diperlukan untuk mencapai tujuan itu. Jadi jika seorang telah diterima, ditempatkan pada suatu organisasi / unit kerja tertentu mereka harus di kelola agar menunjukkan kinerja yang baik. Siapa yang bertanggung jawab terhadap kinerja mereka adalah setiap pemimpin pada semua level.

Irawan, et.al., (1997: 11) kinerja (performance) adalah hasil kerja yang bersifat konkret, dapat diamati, dan dapat diukur. Jika kita mengenal tiga macam tujuan, yaitu tujuan oraganisasi, tujuan unit, dan tujuan karyawan, maka kita juga mengenal tiga macam kinerja, yaitu kinerja organisasi, kinerja unit dan kinerja karyawan.

Dessler (2006: 87) berpendapat kinerja (prestasi kerja) karyawan adalah prestasi aktual karyawan di bandingkan dengan prestasi yang diharapkan dari karyawan. Prestasi kerja yang diharapkan adalah prestasi standar yang disusun sebagai acuan sesuai dengan posisinya dibandingkan dengan standar yang di buat. Selain itu dapat juga dilihat kinerja dari karyawan terhadap karyawan lainnya.

Kinerja karyawan adalah tingkat hasil kerja karyawan dalam mencapai persyaratan-persyaratan pekerjaan yang diberikan. Kinerja adalah hasil kerja karyawan baik dari segi kualitas maupun kuantitas berdasarkan standar kerja yang telah ditetapkan (Simamora, 2007: 500).

Mathis dan Jackson (2006) menyebutkan, ada beberapa dimensi dari kinerja, diantaranya adalah : Kuantitas dari hasil, Kualitas dari hasil, Ketepatan waktu dari hasil, Kehadiran, Kemampuan untuk bekerja sama.

Dimensi Kinerja menurut Gomes, F.C., et.al., (2001) memperluas dimensi prestasi kerja karyawan yang berdasarkan : Quantity work; Jumlah kerja yang dilakukan dalam suatu periode waktu yang ditentukan. Quality of work; Kualitas kerja berdasarkan syarat-syarat kesesuaian dan kesiapannya. Job Knowledge; Luasnya pengetahuan mengenai pekerjaan dan ketrampilannya. Creativeness; Keaslian gagasangagasan yang dimunculkan dan tindakan-tindakan untuk menyelesaikan persoalan-persoalan yang timbul.

Sedangkan menurut Bernarddin dan Russel (dalam Ruky, 2006: 15) memberikan pengertian sebagai berikut performance is defined as the record of outcomes produkced on a specified job function or activity during time period. Prestasi atau kinerja adalah catatan tentang hasil-hasil yang diperoleh dari fungsi-fungsi pekerjaan tertentu atau kegiatan selama kurun waktu tertentu. Bernarddin dan Russel, (1995), mengajukan enam kriteria primer yang dapat digunakan untuk mengukur kinerja : Quality, merupakan tingkat seberapa jauh proses atau hasil pelaksanaan kegiatan mendekati kesempurnaan atau mendekati tujuan yang diharapkan. Quantity, merupakan jumlah yang dihasilkan, misalnya jumlah rupiah, jumlah unit, jumlah siklus kegiatan yang diselesaikan. Time liness, adalah tingkat seberapa jauh suatu kegiatan diselesaikan pada waktu yang dikehendaki, dengan memperhatikan koordinasi out put lain serta waktu yang tersedia untuk kegiatan lain. Cost effectiveness, adalah tingkat seberapa jauh penggunaan daya organisasi (manusia, keuangan, tehnologi, material dimaksimalkan) untuk mencapai hasil tertinggi, atau pengurangan kerugian dan setiap inti penggunaan sumber daya. Need for supervision, merupakan tingkat seberapa jauh seorang karyawan dapat melaksanakan suatu fungsi pekerjaan tanpa memerlukan pengawasan seseorang supervisor untuk mencegah tindakan yang kurang diinginkan. Interpersonal Impact, merupakan tingkat seberapa jauh karyawan memelihara harga diri, nama baik dan kerja sama diantara rekan kerja dan bawahan.

Soedjono (2005) menyebutkan 6 kriteria yang dapat digunakan untuk mengukur kinerja karyawan secara individu yakni : Kualitas. Hasil pekerjaan yang dilakukan mendekati sempurna atau memenuhi tujuan yang diharapkan dari pekerjaan tersebut. Kuantitas. Jumlah yang dihasilkan atau jumlah aktivitas yang dapat diselesaikan. Ketepatan waktu, yaitu dapat menyelesaikan pada waktu yang telah ditetapkan serta memaksimalkan waktu yang tersedia untuk aktivitas yang lain. Efektivitas. Pemanfaatan secara maksimal sumber daya yang ada pada organisasi untuk meningkatkan keuntungan dan mengurangi kerugian. Kemandirian, yaitu dapat melaksanakan kerja tanpa bantuan guna menghindari hasil yang merugikan. Komitmen kerja, yaitu komitmen kerja antara karyawan dengan organisasinya dan Tanggung jawab karyawan terhadap organisasinya.

Tidak semua kriteria pengukuran kinerja dipakai dalam suatu penilaian kinerja karyawan, tentu hal ini harus disesuaikan dengan jenis pekerjaan yang akan dinilai.

Penulis mensinergikan pendapat para ahli sebagai indikator kinerja karyawan dalam hal penelitian ini (Mathis dan Jackson (2006), Gomes, F.C., et.al., (2001), Bernarddin dan Russel (1995), dan Soedjono (2005). Dimensi atau indikator kinerja karyawan dalam penelitian ialah sebagai berikut : Quantity of work (jumlah yang dapat dihasilkan), Quality of work (mutu hasil pekerjaan), Time liness (ketepatan waktu), Attendance (kehadiran), Ability to cooperation (kemampuan bekerjasama), Job knowledge (pengetahuan tentang pekerjaan dan keterampilan), Creativeness (kemampuan berkreasi untuk menyelesaikan persoalan), Cost effectiveness (pendayagunaan man, money, material \& technology dengan hasil yang maksimal. Need supervision (mampu menyelesaikan pekerjaan tanpa pengawasan 
supervisor), Interpersonal impact (kemampuan memelihara harga diri / nama baik, dan dapat bekerjsama dengan karyawan / karyawan lainnya. Outonomous (kemandirian), Work commitment (komitmen pada pekerjaan), Trust (tanggung jawab atau kepercayaan).

\section{METHODS OF RESEARCH 1. Research Design}

Menurut Mohammad Nazir (2002 : 99) bahwa yang dimaksud dengan rancangan penelitian adalah semua proses yang diperlukan dalam perencanaan dan pelaksanaan penelitian. Dalam rancangan ini dibutuhkan suatu gambar atau diagram yang dapat memberikan petunjuk awal terhadap kejelasan penelitian lebih lanjut, sehingga dapat memudahkan analisis data selanjutnya. Penelitian ini digunakan untuk menjelaskan seberapa besar pengaruh dari variabel laten yaitu Person Job Fit, dan Person Organization Fit, Terhadap Organizational Citizenship Behavior dan Kinerja Karyawan Universitas Islam Kalimantan Muhammad Arsyad Al Banjari Banjarmasin.

Penelitian ini mengidentifikasi hubungan causal research antara berbagai variabel. Dengan Explanatory census method. Pengertian metode census ini di mana informasi dikumpulkan dari seluruh anggota populasi, seperti yang dikemukakan oleh Burhan Bungin (2009 : 112) bahwa : Umumnya pengertian census merupakan pengertian sampel total dari anggota populasi, di mana informasi dikumpulkan dari seluruh populasi.

Tujuan census dapat merupakan pengumpulan data, yang bersifat menerangkan atau menjelaskan, mempelajari fenomena dengan hubungan variabel penelitian.

\section{Population and Sampling}

Populasi menurut Sugiarto (2001: 27) adalah keseluruhan unit atau individu dalam ruang lingkup yang ingin diteliti. Populasi penelitian ini ialah keseluruhan Karyawan Universitas Islam Kalimantan Muhammad Arsyad Al Banjari Banjarmasin yakni sebanyak 105 orang.

Berdasarkan formula census tersebut, maka besarnya ukuran sampel responden dalam penelitian ialah sama dengan besarnya jumlah populasi yakni sebanyak 105 orang. Selanjutnya untuk melakukan analisis dengan menggunakan Analisis Structural Equation Model (SEM), menurut Ferdinand (2006), Sampel responden yang digunakan harus memenuhi syarat yakni antara 100 sampai dengan 200 orang responden. Dengan demikian jumlah sampel sebanyak 105 orang responden telah memenuhi kriteria SEM.

\section{Methods of Data Collection}

Data yang digunakan dalam penelitian ini yaitu yang memenuhi syarat ; validitas dan reliabilitas. Jenis data yang digunakan dalam penelitian ini adalah data kuantitatif, yang mengukur pengaruh person job fit, dan person organization fit, terhadap $\mathrm{OCB}$, dan kinerja karyawan. Berdasarkan skala ukurannya, jenis data yang digunakan adalah data ordinal, interval dan ratio di mana selain mengandung unsur penamaan dan urutan, juga memiliki sifat interval bermakna dan dapat diperbandingkan.

Sumber data dalam penelitian ini merupakan data primer dan data sekunder. Data primer yaitu data yang diperoleh secara langsung dari responden melalui penyebaran angket. Dan data sekunder yaitu data yang diperoleh dari pihak lain yang telah mengumpulkan terlebih dahulu dan menerbitkannya.

Penelitian ini bertujuan menguji dan menganalisis hubungan kausal antara variabel eksogen dan endogen baik endogen intervening maupun endogen tergantung, sekaligus memeriksa validitas dan reliabilitas instrumen penelitian secara keseluruhan. Oleh karena itu digunakan teknik analisis Structural Equation-Model (SEM) dengan menggunakan paket program AMOS (Analysis of Moment Structure) versi 22.0

\section{Method of Data Analysis}

\subsection{Uji Validitas}

Ghozali (2011), menyatakan bahwa validitas mempunyai arti seberapa besar ketepatan dan kecermatan suatu alat ukur dalam melakukan fungsi ukurnya, atau dengan kata lain suatu alat pengukur dapat dikatakan memiliki validitas tinggi apabila alat pengukur tersebut menjalankan fungsi ukurnya dengan baik, atau memberikan hasil ukur yang sesuai dengan maksud dilakukannya pengukuran. Suatu alat ukur yang valid, tidak sekedar mampu mengungkapkan data dengan tepat dan memberikan gambaran yang cermat mengenai data tersebut. Cermat artinya pengukuran itu mampu memberikan gambaran mengenai perbedaan yang sekecilkecilnya di antara subjek yang satu dengan yang lainnya. Loading factor sudah memenuhi convergent validity yaitu apabila $\geq 0,5$ (Ghozali, 2011).

\subsection{Uji Reliabilitas}

Suatu alat ukur di samping valid, juga harus reliabel. Suatu alat pengukur dinyatakan reliabel jika alat ukur tersebut memberi hasil yang konsisten, atau dengan kata lain menunjukkan seberapa besar pengukuran dapat memberikan hasil yang relatif tidak berbeda bila dilakukan 
pengukuran kembali terhadap subyek yang sama. Reliabilitas menunjuk pada adanya konsistensi internal dan stabilitas nilai hasil skala pengukuran tertentu. Reliabillitas berkonsentrasi pada masalah akurasi pengukuran dan hasilnya (Sarwono, 2002). Pendekatan yang digunakan adalah menilai besar composite reliability serta variance - extrated dari masing-masing konstruk. Dengan rumusan sebagai berikut :

$$
\text { Construct }- \text { reliability }=\frac{\left(\sum \text { Std Loading }\right)^{2}}{\left(\sum \text { Std Loading }\right)^{2}+\sum \varepsilon j}
$$

Sumber: Ferdinand, 2006

Di mana : Standard Loading diperoleh langsung dari standardised loading untuk indikator (dari perhitungan AMOS). $€ j$ adalah measurement error dari setiap indikator. Nilai variance extrated ini direkomendasikan pada tingkat paling sedikit 0,50 (Ferdinand,2006).

Nilai batas yang digunakan untuk menilai sebuah tingkat reliabilitas yang dapat diterima adalah 0,60 (Nunully dalam Arikunto, 2003). Bila penelitian yang dilakukan adalah ekploratori maka nilai di bawah 0,60 pun masih dapat diterima sepanjang disertai dengan alasan-alasan empirik yang terlihat dalam proses eksplorasi.

\subsection{Pengujian Hipotesis}

Penelitian tentang Pengaruh Person job fit, dan Person organization fit, terhadap OCB, dan Kinerja karyawan Universitas Islam Kalimantan Muhammad Arsyad Al Banjari Banjarmasin. Dalam melakukan pengujian hipotesis, data yang diperoleh selanjutnya diolah sesuai dengan kebutuhan analisis. Untuk kepentingan pembahasan, data diolah dan dipaparkan berdasarkan prinsip-prinsip statistik deskriptif, sedangkan untuk kepentingan analisis dan pengujian hipotesis digunakan statistik inferensial. Untuk menguji hipotesis digunakan analisis multivariat dengan Structural Equation Model (SEM) dengan menggunakan program AMOS versi 22.0 Pengujian apakah hipotesis yang diajukan dapat diterima dilakukan dengan jalan membandingkan nilai probabilitas (p) dengan taraf signifikan $\alpha$ yang ditentukan sebesar 0,05.- Apabila nilai probabilitas (p) lebih kecil dari nilai $\alpha(0,05)$, maka hipotesis tersebut dapat diterima. Begitu pula sebaliknya, jika nilai probabilitas (p) lebih besar dari nilai $\alpha(0,05)$, maka hipotesis tersebut tidak diterima. Namun, sebelum dilakukan pengujian hipotesis, maka terlebih dahulu dilakukan analysis factor confirmatory guna melihat dimensi-dimensi yang dapat digunakan untuk membentuk faktor atau konstruk.

\subsection{Analisis Model SEM}

Analisis data secara statistik inferensial dengan menggunakan teknik Structural Equation Model (SEM) memungkinkan seorang peneliti menguji beberapa variable dependen sekaligus, dengan beberapa variabel independen (Ferdinand, 2006). Dengan demikian indeks-indeks yang dapat digunakan untuk menguji kelayakan sebuah model dapat diringkas dalam Tabel berikut ini.

Tabel 1.

Index Goodness of Fit

\begin{tabular}{lll}
\hline No. & \multicolumn{1}{c}{ Goodness of fit index } & \multicolumn{1}{c}{ Cut-off value } \\
\hline 1. & $\mathrm{X}^{2}$ (chi-square) & Diharapkan kecil \\
\hline 2. & Significance probability & $\geq 0.05$ \\
\hline 3. & $\mathrm{X}^{2} / \mathrm{df}(\mathrm{CMlN} / \mathrm{DF})$ & $\leq 2.00$ \\
\hline 4. & GF1 & $\geq 0.90$ \\
\hline 5. & AGF1 & $\geq 0.90$ \\
\hline 6. & TL1 & $\geq 0.95$ \\
\hline 7. & CF1 & $\geq 0.95$ \\
\hline 8. & RMSEA & $\leq 0.08$ \\
\hline
\end{tabular}

Sumber; Ferdinand (2006)

Pengujian hipotesis, dilakukan dengan menguji signifikansi regresi berdasarkan uji $\mathrm{F}$ pada $\alpha=0,05$ pada masing-masing koefisien persamaan, baik secara langsung maupun secara parsial. Setelah dilakukan pengujian terhadap asumsi dasar SEM dan terhadap uji kesesuaian dan uji statistik, langkah berikutnya adalah melakukan modifikasi terhadap model yang tidak memenuhi syarat pengujian yang telah dilakukan. Setelah model diestimasi, residualnya haruslah kecil atau mendekati nol dan distribusi frekuensi dari kovarians residual harus bersifat simetrik (Tabachnick and Fidell. 2007). Hair et al. (1998) memberikan sebuah pedoman untuk mempertimbangkan perlu tidaknya modifikasi terhadap sebuah model, yaitu dengan melihat sejumlah residual yang dihasilkan oleh model. Bila jumlah residual lebih besar dari $5 \%$ dari semua residual kovarians yang dihasilkan oleh model, maka modifikasi perlu dipertimbangkan. Bila ditemukan nilai residual yang dihasilkan oleh model cukup besar $(>2,58)$, maka cara lain dalam memodifikasi adalah dengan mempertimbangkan untuk menambah jalur baru terhadap model yang diestimasi. 


\section{RESULTS AND DISCUSSION}

\section{Uji Validitas Instrument}

Uji validitas Instrument dilakukan untuk mengetahui tingkat kevalidan atau derajat ketepatan dari instrument yang digunakan dalam pengumpulan data. Suatu instrumen diusahakan valid apabila mampu mengukur apa yang diinginkan dan dapat mengungkap data dari variabel yang diteliti dengan tepat. Tinggi rendahnya validitas menunjukkan sejauhmana data yang terkumpul tidak menyimpang dari gambaran tentang variabel yang dimaksud.

Valid atau tidaknya suatu item/indikator instrumen dapat diketahui dengan membandingkan indeks korelasi Pearson Product Moment dengan level signifikansi dengan degree of convidence $95 \%$, dengan nilai kritisnya $r_{\text {tabel }}$ pada tingkat signifikansi $\alpha=5 \%$ dengan derajat bebas $=n-(k+1)$ $=105-(4+1)=100$ adalah sebesar 0,196. Adapun hasil Uji Validitas \& Reliabilitas Instrument dapat dijelaskan seperti di bawah ini:

\subsection{Validitas Person Job Fit $\left(\mathrm{X}_{1}\right)$}

Tabel 2

Hasil Uji Validitas Person Job Fit $\left(\mathrm{X}_{1}\right)$

\begin{tabular}{cccccc}
\hline \multirow{2}{*}{ Variabel } & Item & $\begin{array}{c}\text { Koefisien } \\
\text { Korelasi }\end{array}$ & $\mathrm{r}_{\text {tabel }}$ & Sig & Keterangan \\
\hline Person Job Fit $\left(\mathrm{X}_{1}\right)$ & $\mathrm{P} 1$ & 0,409 & 0,196 & 0,000 & Valid \\
\cline { 2 - 6 } & $\mathrm{P} 2$ & 0,418 & 0,196 & 0,000 & Valid \\
\cline { 2 - 6 } & $\ldots$. & $\ldots$ & $\ldots$. & $\ldots$. & Valid \\
\cline { 2 - 6 } & $\ldots$. & $\ldots$ & $\ldots$. & $\ldots$. & Valid \\
\hline & $\ldots$. & $\ldots$. & $\ldots$. & $\ldots$. & Valid \\
\cline { 2 - 6 } & $\mathrm{P} 23$ & 0,496 & 0,196 & 0,000 & Valid \\
\cline { 2 - 6 } & $\mathrm{P} 24$ & 0,433 & 0,196 & 0,000 & Valid \\
\hline
\end{tabular}

Hasil uji Korelasi Product Moment pada Variabel Person Job Fit $\left(\mathrm{X}_{1}\right)$ berkorelasi secara signifikan dengan Tabel skor yang ditunjukkan nilai indeks korelasi Pearson Product Moment lebih besar dari $r_{\text {tabel }}$ sehingga instrument terhadap semua indikator yang membentuk variabel Person Job Fit $\left(\mathrm{X}_{1}\right)$ dinyatakan valid dan dapat digunakan untuk menguji hipotesis.

\subsection{Validitas Person Organization Fit $\left(\mathrm{X}_{2}\right)$}

Tabel 3

Hasil Uji Validitas Person Organization Fit $\left(\mathrm{X}_{2}\right)$

\begin{tabular}{lccccc}
\hline \multirow{2}{*}{ Variabel } & Item & $\begin{array}{c}\text { Koefisien } \\
\text { Korelasi }\end{array}$ & $\mathrm{r}_{\text {tabel }}$ & Sig & Keterangan \\
\hline Person Organization & $\mathrm{P} 25$ & 0,677 & 0,196 & 0,000 & Valid \\
\cline { 2 - 6 } Fit $\left(\mathrm{X}_{2}\right)$ & $\mathrm{P} 26$ & 0,695 & 0,196 & 0,000 & Valid \\
\cline { 2 - 6 } & & & & & Valid \\
\cline { 2 - 6 } & & & & & Valid \\
\cline { 2 - 6 } & $\mathrm{P} 38$ & 0,673 & 0,196 & 0,000 & Valid \\
\cline { 2 - 6 } & $\mathrm{P} 39$ & 0,631 & 0,196 & 0,000 & Valid \\
\hline
\end{tabular}

Hasil uji Korelasi Product Moment pada Variabel Person Organization Fit $\left(\mathrm{X}_{2}\right)$ berkorelasi secara signifikan dengan tabel skor yang ditunjukkan nilai indeks korelasi Pearson Product Moment lebih besar dari $r_{\text {tabel }}$ sehingga instrument terhadap semua indikator yang membentuk variabel Person Organization Fit $\left(\mathrm{X}_{2}\right)$ dinyatakan valid dan dapat digunakan untuk menguji hipotesis

\subsection{Validitas Organizational Citizenship Behaviour (Z)}

Tabel 4

Hasil Uji Validitas Organizational Citizenship Behaviour (Z)

\begin{tabular}{lccccc}
\hline \multicolumn{1}{c}{ Variabel } & Item & $\begin{array}{c}\text { Koefisien } \\
\text { Korelasi }\end{array}$ & $\mathrm{r}_{\text {tabel }}$ & Sig & Keterangan \\
\hline $\begin{array}{l}\text { Organizational } \\
\text { Citizenship Behaviour } \\
\text { (Z) }\end{array}$ & $\mathrm{P} 40$ & 0,678 & 0,196 & 0,000 & Valid \\
\cline { 2 - 6 } & $\mathrm{P} 41$ & 0,514 & 0,196 & 0,000 & Valid \\
\cline { 2 - 6 } & ----- & --- & --- & --- & Valid \\
\cline { 2 - 6 } & ------- & Valid \\
\cline { 2 - 6 } & P62 & 0,581 & 0,196 & 0,000 & Valid \\
\cline { 2 - 6 } & P63 & 0,565 & 0,196 & 0,000 & Valid \\
\hline
\end{tabular}

Hasil uji Korelasi Product Moment pada Variabel Organizational Citizenship Behaviour (Z) berkorelasi secara signifikan dengan tabel skor yang ditunjukkan nilai indeks korelasi Pearson Product Moment lebih besar dari $\mathrm{r}_{\text {tabel }}$ sehingga instrument terhadap semua indikator yang membentuk Variabel Organizational Citizenship Behavior (Z) dinyatakan valid dan dapat digunakan untuk menguji hipotesis.

\subsection{Validitas Kinerja Karyawan (Y)}

Tabel 5

Hasil Uji Validitas Kinerja Karyawan (Y)

\begin{tabular}{cccccc}
\hline \multirow{2}{*}{ Variabel } & Item & $\begin{array}{c}\text { Koefisien } \\
\text { Korelasi }\end{array}$ & $\mathrm{r}_{\text {tabel }}$ & Sig & Keterangan \\
\hline Kinerja Karyawan $(\mathrm{Y})$ & $\mathrm{P} 64$ & 0,609 & 0,196 & 0,000 & Valid \\
\cline { 2 - 6 } & $\mathrm{P} 65$ & 0,599 & 0,196 & 0,000 & Valid \\
\cline { 2 - 6 } & $\mathrm{P} 66$ & 0,543 & 0,196 & 0,000 & Valid \\
\cline { 2 - 6 } & $\ldots \ldots$ & $\ldots$. & $\ldots$. & $\ldots$. & Valid \\
\cline { 2 - 6 } & $\ldots$. & $\ldots$. & $\ldots$. & $\ldots$. & Valid \\
\cline { 2 - 6 } & $\ldots .$. & $\ldots$. & $\ldots$. & $\ldots$. & Valid \\
\cline { 2 - 6 } & $\mathrm{P} 101$ & 0,671 & 0,196 & 0,000 & Valid \\
\cline { 2 - 6 } & P102 & 0,617 & 0,196 & 0,000 & Valid \\
\hline
\end{tabular}

Hasil uji Korelasi Product Moment pada Variabel Kinerja Karyawan (Y) berkorelasi secara signifikan dengan tabel skor yang ditunjukkan nilai indeks korelasi Pearson Product Moment lebih besar dari $r_{\text {tabel }}$ sehingga instrument terhadap semua indikator yang membentuk Kinerja Karyawan (Y) dinyatakan valid dan dapat digunakan untuk menguji hipotesis. 


\section{Uji Reliabilitas Instrument}

Uji Reliabilitas digunakan untuk menguji konsistensi alat ukur yang digunakan. Kuesioner atau angket sebagai alat ukur dinyatakan konsisten apabila mengukur sesuatu secara berulang kali memberikan hasil yang sama atau konsisten. Nunully dalam Arikunto (2003), suatu indikator dinyatakan reliabel jika nilai alpha Cronbach > 0,60. Hasil uji reliabilitas Instrument dapat dilihat sebagai berikut.

Tabel 6

Hasil Uji Reliabilitas Instrumen Angket

\begin{tabular}{lcc}
\hline \multicolumn{1}{c}{ Variabel } & Reliabilitas & Keterangan \\
\hline Person Job Fit $\left(\mathrm{X}_{1}\right)$ & 0,888 & Reliabel \\
\hline $\begin{array}{l}\text { Person Organization } \\
\text { Fit }\left(\mathrm{X}_{2}\right)\end{array}$ & 0,912 & Reliabel \\
\hline $\begin{array}{l}\text { Organizational } \\
\text { Citizenship Behaviour }(\mathrm{Z})\end{array}$ & 0,930 & Reliabel \\
\hline Kinerja Karyawan $(\mathrm{Y})$ & 0,959 & Reliabel \\
\hline
\end{tabular}

Dari hasil pengujian reliabilitas seperti tertera pada Tabel 6 dapat dinyatakan bahwa semua variabel yang diteliti dinyatakan reliable karena nilainya lebih besar dari 0,6. Kesimpulan yang dapat diambil bahwa nilai reliabilitasnya dikategorikan sangat tinggi karena berada pada kisaran di atas 0,80 .

\section{Uji Validitas dan Reliabilitas Konstruks (variabel) dalam Analisis SEM}

Bagian ini menyajikan hasil analisis awal sebelum pengujian full model persamaan struktural (SEM). Variabel laten dalam model penelitian akan diperiksa dengan pembahasan tingkat keandalan dalam membangun variabel melalui model Confirmatory Factor Analysis (CFA).

Uji Confirmatory Factor Analysis (CFA) dan Uji Convergent Validitas dilakukan bertujuan untuk mengkonfirmasi setiap indikator yang sudah dibuat berdasarkan penelitian terdahulu maupun teori yang sudah ada dapat digunakan untuk menjelaskan konstruk variabel penelitian yaitu Person Job Fit, dan Person Organization Fit, Organizational Citizenship Behavior, dan Kinerja Karyawan. Hasil Uji Confirmatory Factor Analysis (CFA) memenuhi kriteria apabila nilai Critical Ratio (CR) $>1,96$ dengan Probability $<0,05$ dan Uji Convergent Validitas memenuhi kriteria apabila apabila Loading Factor atau Standardized Loading Estimate $>0,5$.

\subsection{Uji Validitas Konstruk Person Job Fit $\left(\mathrm{X}_{1}\right)$}

Pengujian validitas masing-masing nilai loading untuk diuji signifikansi pada setiap indikator pembentuk konstruk Person Job Fit $\left(\mathrm{X}_{1}\right)$ sebagai berikut.

Tabel 7

Uji CFA Person Job Fit $\left(\mathrm{X}_{1}\right)$

\begin{tabular}{lcccc}
\hline \multicolumn{1}{c}{ Indikator } & SLE & CR & P & Keterangan \\
& & & & \\
\hline Knowledge $\left(\mathrm{X}_{1.1 .}\right)$ & 0,586 & fix & fix & Valid \\
\hline Skill $\left(\mathrm{X}_{1.2 .}\right)$ & 0,537 & 2,896 & 0,004 & Valid \\
\hline Abilities $\left(\mathrm{X}_{1.3 .}\right)$ & 0,575 & 1,959 & 0,050 & Valid \\
\hline Social Skill $\left(\mathrm{X}_{1.4 .}\right)$ & 0,554 & 2,446 & 0,014 & Valid \\
\hline Personal Needs $\left(\mathrm{X}_{1.5 .}\right)$ & 0,799 & 2,649 & 0,008 & Valid \\
\hline Value $\left(\mathrm{X}_{1.6 .}\right)$ & 0,752 & 2,670 & 0,008 & Valid \\
\hline Interest $\left(\mathrm{X}_{1.7 .}\right)$ & 0,700 & 2,617 & 0,009 & Valid \\
\hline Personality Traits $\left(\mathrm{X}_{1.8 .}\right)$ & 0,619 & 2,600 & 0,009 & Valid \\
\hline
\end{tabular}

Berdasarkan Tabel 7 di atas dapat dijelaskan bahwa faktor nilai loading Knowledge $\left(\mathrm{X}_{1.1}\right)$ adalah 0,586 lebih besar dari 0,5 yang berarti indikator tersebut valid dapat digunakan untuk mengukur konstruk person job fit. Demikian seterusnya nilai faktor loading Skill $\left(\mathrm{X}_{1.2}\right)$ adalah 0,537, Abilities $\left(\mathrm{X}_{1.3}\right)$ adalah 0,575 , Social Skill $\left(\mathrm{X}_{1.4}\right)$ adalah 0,554 , Personal Needs $\left(X_{1.5}\right)$ adalah 0,799 , Value $\left(\mathrm{X}_{1.6}\right)$ adalah 0,752 , Interest $\left(\mathrm{X}_{1.7 .}\right)$ adalah 0,700 , dan Personality Traits $\left(\mathrm{X}_{1.8}\right)$ adalah 0,619 yang kesemua indikator memiliki nilai faktor loading lebih besar dari 0,5. Hal ini berarti bahwa kesemua indikator pembentuk variabel person job fit tersebut adalah valid dan dapat digunakan untuk mengukur konstruk person job fit.

\subsection{Uji Validitas Konstruk Person Organization Fit $\left(\mathbf{X}_{2}\right)$}

Pengujian validitas masing-masing nilai loading untuk diuji signifikansi pada setiap indikator pembentuk konstruk Person Organization Fit $\left(\mathrm{X}_{2}\right)$ sebagai berikut.

Tabel 8

Uji CFA Person Organization Fit $\left(\mathrm{X}_{2}\right)$

\begin{tabular}{llllc}
\hline \multicolumn{1}{c}{ Indikator } & SLE & CR & P & Keterangan \\
\hline Knowledge $\left(\mathrm{X}_{2.1 .}\right)$ & 0,721 & fix & fix & Valid \\
\hline Skill $\left(\mathrm{X}_{2.2 .}\right)$ & 0,703 & 8,258 & $* * *$ & Valid \\
\hline Abilities $\left(\mathrm{X}_{2.3 .}\right)$ & 0,711 & 8,518 & $* * *$ & Valid \\
\hline Personal Needs $\left(\mathrm{X}_{2.4 .}\right)$ & 0,642 & 7,758 & $* * *$ & Valid \\
\hline Personal Value $\left(\mathrm{X}_{2.5 .}\right)$ & 0,690 & 8,235 & $* * *$ & Valid \\
\hline
\end{tabular}

Berdasarkan Tabel 8 di atas dapat dijelaskan bahwa faktor nilai loading Knowledge $\left(\mathrm{X}_{2.1}\right)$ adalah 0,721 lebih besar dari 0,5 yang berarti indikator tersebut valid dapat digunakan untuk mengukur konstruk person organization fit. Demikian seterusnya nilai faktor loading Skill $\left(\mathrm{X}_{2.2}\right.$ ) adalah 0,703, Abilities $\left(\mathrm{X}_{2.3}\right)$ adalah 0,711 , Personal Needs 
$\left(\mathrm{X}_{2.4 .}\right)$ adalah 0,642 dan Personal Value $\left(\mathrm{X}_{2.5 .}\right)$ adalah 0,690 yang kesemua indikator memiliki nilai faktor loading lebih besar dari 0,5. Hal ini berarti bahwa kesemua indikator pembentuk variabel person organization fit tersebut adalah valid dan dapat digunakan untuk mengukur konstruk person organization fit.

\subsection{Uji Validitas Konstruk Organizational Citizenship Behaviour (Z)}

Pengujian validitas masing-masing nilai loading untuk diuji signifikansi pada setiap indikator pembentuk konstruk Organizational Citizenship Behaviour (Z) sebagai berikut.

Tabel 9

Uji Validitas Organizational Citizenship Behaviour (Z)

\begin{tabular}{lcccc}
\hline \multicolumn{1}{c}{ Indikator } & SLE & CR & P & Keterangan \\
\hline Altruism $\left(\mathrm{Z}_{1}\right)$ & 0,629 & 7,071 & $* * *$ & Valid \\
\hline Courtesy $\left(\mathrm{Z}_{2 .}\right)$ & 0,639 & 7,213 & $* * *$ & Valid \\
\hline Sportmanship $\left(\mathrm{Z}_{3}\right)$ & 0,641 & 7,206 & $* * *$ & Valid \\
\hline Civic Virtue $\left(\mathrm{Z}_{4}\right)$ & 0,661 & 7,285 & $* * *$ & Valid \\
\hline Conscientiousness $\left(\mathrm{Z}_{5}\right)$ & 0,720 & 7,844 & $* * *$ & Valid \\
\hline $\begin{array}{l}\text { Organizational } \\
\text { Compliance }\left(\mathrm{Z}_{6}\right)\end{array}$ & 0,701 & 7,711 & $* * *$ & Valid \\
\hline $\begin{array}{l}\text { Organizational } \\
\text { Loyalty }\left(\mathrm{Z}_{7}\right)\end{array}$ & 0,667 & 7,395 & $* * *$ & Valid \\
\hline Self Development $\left(\mathrm{Z}_{8}\right)$ & 0,656 & fix & fix & Valid \\
\hline
\end{tabular}

Berdasarkan Tabel 9 di atas dapat dijelaskan bahwa faktor nilai loading Altruism $\left(\mathrm{Z}_{1}\right)$ adalah 0,629 lebih besar dari 0,5 yang berarti indikator tersebut valid dapat digunakan untuk mengukur konstruk Organizational Citizenship Behavior. Demikian seterusnya nilai faktor loading Courtesy $\left(\mathrm{Z}_{2}\right)$ adalah 0,629 , Sportmanship $\left(\mathrm{Z}_{3}\right)$ adalah 0,639, Civic Virtue $\left(\mathrm{Z}_{4}\right)$ adalah 0,661, Conscientiousness $\quad\left(\mathrm{Z}_{5}\right) \quad$ adalah 0,720 , Organizational Compliance $\left(\mathrm{Z}_{6}\right)$ adalah 0,701, Organizational Loyalty $\left(\mathrm{Z}_{7}\right)$ adalah 0,667, dan Self Development $\left(\mathrm{Z}_{8}\right)$ adalah 0,656 yang kesemua indikator memiliki nilai faktor loading lebih besar dari 0,5. Hal ini berarti bahwa kesemua indikator pembentuk variabel Organizational Citizenship Behavior tersebut adalah valid dan dapat digunakan untuk mengukur konstruk Organizational Citizenship Behavior.

\subsection{Uji Validitas Konstruk Kinerja Karyawan} (Y)

Pengujian validitas masing-masing nilai loading untuk diuji signifikansi pada setiap indikator pembentuk konstruk Kinerja Karyawan (Y) sebagai berikut.
Tabel 10

Uji Validitas Kinerja Karyawan (Y)

\begin{tabular}{llllc}
\hline \multicolumn{1}{c}{ Indikator } & SLE & CR & P & Keterangan \\
\hline Quantity of Work $\left(\mathrm{Y}_{1 .}\right)$ & 0,598 & fix & fix & Valid \\
\hline Quality of Work $\left(\mathrm{Y}_{2 .}\right)$ & 0,614 & 8,565 & $* * *$ & Valid \\
\hline Time Lines $\left(\mathrm{Y}_{3 .}\right)$ & 0,763 & 6,307 & $* * *$ & Valid \\
\hline Attendance $\left(\mathrm{Y}_{4 .}\right)$ & 0,671 & 5,758 & $* * *$ & Valid \\
\hline Ability to Cooperation $\left(\mathrm{Y}_{5 .}\right)$ & 0,745 & 6,188 & $* * *$ & Valid \\
\hline Job Knowledge $\left(\mathrm{Y}_{6 .}\right)$ & 0,747 & 6,171 & $* * *$ & Valid \\
\hline Creativeness $\left(\mathrm{Y}_{7 .}\right)$ & 0,693 & 5,864 & $* * *$ & Valid \\
\hline Cost Effectiveness $\left(\mathrm{Y}_{8 .}\right)$ & 0,680 & 5,799 & $* * *$ & Valid \\
\hline Need Supervision $\left(\mathrm{Y}_{9}\right)$ & 0,623 & 5,390 & $* * *$ & Valid \\
\hline Interpersonal Impact $\left(\mathrm{Y}_{10 .}\right)$ & 0,767 & 6,232 & $* * *$ & Valid \\
\hline Outonomus $\left(\mathrm{Y}_{11 .}\right)$ & 0,795 & 6,410 & $* * *$ & Valid \\
\hline Work Commitment $\left(\mathrm{Y}_{12 .}\right)$ & 0,698 & 5,870 & $* * *$ & Valid \\
\hline Trust $\left(\mathrm{Y}_{13 .}\right)$ & 0,747 & 6,121 & $* * *$ & Valid
\end{tabular}

Berdasarkan Tabel 10 di atas dapat dijelaskan bahwa faktor nilai loading Quantity of Work ( $\left.\mathrm{Y}_{1 .}\right)$ adalah 0,598 lebih besar dari 0,5 yang berarti indikator tersebut valid dapat digunakan untuk mengukur konstruk Kinerja Karyawan. Demikian seterusnya nilai faktor loading Quality of Work $\left(\mathrm{Y}_{2}\right)$ adalah 0,614, Time Lines $\left(\mathrm{Y}_{3}\right)$ adalah 0,763, Attendance $\quad\left(\mathrm{Y}_{4}\right)$ adalah 0,671 , Ability to Cooperation $\left(\mathrm{Y}_{5}\right)$ adalah 0,745, Job Knowledge $\left(\mathrm{Y}_{6}\right)$ adalah 0,747 , Creativeness $\left(\mathrm{Y}_{7 .}\right)$ adalah 0,693, Cost Effectiveness $\left(\mathrm{Y}_{8}\right)$ adalah 0,680, Need Supervision $\left(\mathrm{Y}_{9}\right)$ adalah 0,623, Interpersonal Impact $\left(\mathrm{Y}_{10}\right)$ adalah 0,767, Outonomus $\left(\mathrm{Y}_{11 .}\right)$ adalah 0,795, Work Commitment $\left(\mathrm{Y}_{12 .}\right)$ adalah 0,698 dan Trust ( $\mathrm{Y}_{13}$ ) adalah 0,747 yang kesemua indikator memiliki nilai faktor loading lebih besar dari 0,5. Hal ini berarti bahwa kesemua indikator pembentuk variabel Kinerja Karyawan tersebut adalah valid dan dapat digunakan untuk mengukur konstruk Kinerja Karyawan.

\subsection{Uji Reliabilitas Konstruk Person Job Fit $\left(\mathrm{X}_{1}\right)$}

Pengujian reliabilitas masing-masing nilai loading untuk diuji signifikansi pada setiap indikator pembentuk konstruk Person Job Fit $\left(\mathrm{X}_{1}\right)$ diperoleh dari hasil nilai standard loading dan measurement error.

Tabel 11

Reliabilitas Konstruk Person Job Fit $\left(\mathrm{X}_{1}\right)$

\begin{tabular}{lccc}
\hline \multicolumn{1}{c}{ Indikator } & $\begin{array}{c}\text { Standar } \\
\text { loading }(\lambda)\end{array}$ & $\left(\lambda^{2}\right)$ & $\begin{array}{c}\text { measurement } \\
\text { error }\left(\mathbf{1}-\lambda^{2}\right)\end{array}$ \\
\hline Knowledge $\left(\mathrm{X}_{1.1 .}\right)$ & 0,586 & 0,343 & 0,657 \\
\hline Skill $\left(\mathrm{X}_{1.2 .}\right)$ & 0,537 & 0,288 & 0,712 \\
\hline Abilities $\left(\mathrm{X}_{1.3 .}\right)$ & 0,575 & 0,331 & 0,669 \\
\hline Social Skill $\left(\mathrm{X}_{1.4 .}\right)$ & 0,554 & 0,307 & 0,693 \\
\hline Personal Needs $\left(\mathrm{X}_{1.5 .}\right)$ & 0,799 & 0,638 & 0,362 \\
\hline Value $\left(\mathrm{X}_{1.6 .}\right)$ & 0,752 & 0,566 & 0,434 \\
\hline Interest $\left(\mathrm{X}_{1.7 .}\right)$ & 0,700 & 0,490 & 0,510 \\
\hline Personality Traits $\left(\mathrm{X}_{1.8 .}\right)$ & 0,619 & 0,383 & 0,617 \\
\hline \multicolumn{1}{c}{ Jumlah } & 5,122 & 3,346 & 4,654 \\
\hline
\end{tabular}

Berdasarkan Tabel 11 dilakukan penghitungan nilai reliabilitas konstruk person job fit sebagai berikut :

$$
\frac{(5,122)^{2}}{(5,122)^{2}+4,654}=0,84933
$$


Berdasarkan penghitungan pada Tabel 11 diperoleh nilai reliabilitas konstruk Person Job Fit sebesar 0,84933, artinya ke delapan indikator tersebut di atas adalah reliabel membentuk konstruk Person Job Fit sebesar 84,933\%. Dan melebihi standard Cronbach Alpha menurut Nunully dalam Arikunto (2003) sebesar 0,60 atau 60\%.

Dengan menggunakan cara yang sama diperoleh nilai reliabilitas konstruk Person Organization Fit sebesar 0,81151, artinya ke lima indikator tersebut di atas adalah reliabel membentuk konstruk Person Organization Fit sebesar 81,151\%. Dan melebihi standard Cronbach Alpha menurut Nunully dalam Arikunto (2003) sebesar 0,60 atau $60 \%$.

Besarnya nilai reliabilitas konstruk Organizational Citizenship Behavior sebesar 0,86352, artinya ke delapan indikator tersebut diatas adalah reliabel membentuk konstruk Organizational Citizenship Behavior sebesar 86,352\%. Dan melebihi standard Cronbach Alpha menurut Nunully dalam Arikunto (2003) sebesar 0,60 atau $60 \%$.

Besarnya nilai reliabilitas konstruk Kinerja Karyawan sebesar 0,92758, artinya ke tiga belas indikator tersebut diatas adalah reliabel membentuk konstruk Kinerja Karyawan sebesar 92,758\%. Dan melebihi standard Cronbach Alpha menurut Nunully dalam Arikunto (2003) sebesar 0,60 atau $60 \%$.

\section{Evaluasi Kriteria Kelayakan Model}

Model Struktur Persamaan ini dilakukan untuk melihat berbagai asumsi yang diperlukan dalam penelitian ini, sekaligus apakah perlu dilakukan modifikasi atau tidak dalam Full Model. Berdasarkan Tabel 12 diketahui bahwa ke tujuh parameter goodness of fit indeks terlihat sudah baik, sehingga Model Struktur Persamaan modifikasi seperti pada gambar 1 sebagai berikut :

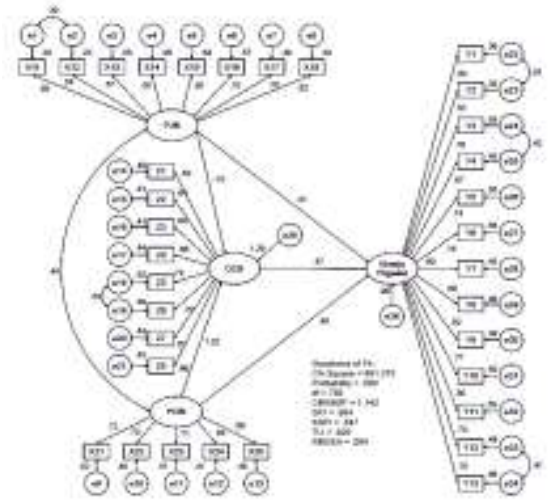

Gambar 1 Model Sructural Equation Model : Person Job fit, dan Person Organization fit, Terhadap

\section{Organizational \\ Citizenship \\ Behaviour dan Kinerja Karyawan}

Berdasarkan hasil analisis faktor konfirmatori diketahui nilai goodness of fit indeks pada Tabel 12 sebagai berikut :

Tabel 12

Goodness of Fit Indeks

\begin{tabular}{lccc}
\hline $\begin{array}{c}\text { Goodness of } \\
\text { Fit index }\end{array}$ & $\begin{array}{c}\text { Cut off } \\
\text { value }\end{array}$ & $\begin{array}{c}\text { Hasil } \\
\text { analisis }\end{array}$ & Evaluasi Model \\
\hline Chi Square & $\begin{array}{c}<\chi^{2} \text { tab } \\
\text { el }\end{array}$ & 891,375 & $\begin{array}{c}\chi^{2} \text { tabel adalah } 892,8985 \\
\chi^{2} \text { hitung }<\chi^{2} \text { tabel = Baik }\end{array}$ \\
\hline RMSEA & $\leq 0,08$ & 0,084 & Baik \\
\hline GFI & $\geq 0,90$ & 0,894 & Marjinal \\
\hline AGFI & $\geq 0,90$ & 0,847 & Marjinal \\
\hline CMIN/DF & $\leq 2,00$ & 1,142 & Baik \\
\hline TLI & $\geq 0,95$ & 0,928 & Baik \\
\hline CFI & $\geq 0,95$ & 0,942 & Baik \\
\hline
\end{tabular}

Sumber : Lampiran 4, data diolah

Berdasarkan Tabel 12 diketahui bahwa ke lina parameter Goodness Of Fit indeks terlihat Baik, dan dua parameter terlihat Marjinal oleh karena itu hasil Model Struktur Persamaan sudah dapat dilakukan sebagai dasar untuk Pengujian AsumsiAsumsi dalam Sructural Equation Model (SEM).

\section{Pengujian Hipotesis Model Persamaan Struktural}

Berdasarkan hasil analisis model persamaan struktural Person Job Fit, dan Person Organization Fit, terhadap Organizational Citizenship Behavior dan Kinerja Karyawan. Pengujian hipotesis dapat dilihat pada Tabel berikut

Tabel 13

Hasil Pengujian Hipotesis

\begin{tabular}{clcccc}
\hline No & Variabel & Koefisien & C.R. & P $_{\text {Value }}$ & Keterangan \\
\hline 1. & Person job fit $\left(\mathrm{X}_{1}\right) \rightarrow$ OCB $(\mathrm{Z})$ & $-0,308$ & $-1,751$ & 0,080 & Tidak Signifikan \\
\hline 2 & $\begin{array}{l}\text { Person organization fit }\left(\mathrm{X}_{2}\right) \rightarrow \\
\text { OCB }(\mathrm{Z})\end{array}$ & 1,342 & 8,124 & $* * *$ & $\begin{array}{l}\text { Sangat } \\
\text { Signifikan }\end{array}$ \\
\hline 3 & $\begin{array}{l}\text { Person job fit }\left(\mathrm{X}_{1}\right) \rightarrow \\
\text { Kinerja karyawan }(\mathrm{Y})\end{array}$ & 0,020 & 0,162 & 0,872 & Tidak Signifikan \\
\hline 4 & $\begin{array}{l}\text { Person organization fit }\left(\mathrm{X}_{2}\right) \rightarrow \\
\text { Kinerja karyawan }(\mathrm{Y})\end{array}$ & 0,421 & 5,799 & $* * *$ & Signifikan \\
\hline 5 & OCB (Z) $\rightarrow$ Kinerja karyawan $(\mathrm{Y})$ & 0,381 & 5,348 & $* * * *$ & Signifikan \\
\hline
\end{tabular}

Sumber : Lampiran 4, data diolah.

Berdasarkan Tabel 13 di atas dapat dijelaskan hasil pengujian hipotesis sebagai berikut :

1. Hipotesis satu $\left(\mathrm{H}_{1}\right)$ menyatakan bahwa Person Job Fit berpengaruh tidak signifikan terhadap Organizational Citizenship Behavior (OCB). Koefisien jalur yang bertanda negatif sebesar 0,308 dengan nilai C.R. sebesar - 1,751 lebih kecil dari 1,96, dan nilai probabilitas sebesar $0,080>\alpha$ sebesar 5\%, artinya Person Job Fit 
berpengaruh tidak signifikan terhadap Organizational Citizenship Behavior (OCB). Jadi hipotesis satu $\left(\mathrm{H}_{1}\right)$ ditolak, artinya Person Job Fit tidak berpengaruh secara signifikan terhadap Organizational Citizenship Behavior (OCB).

2. Hipotesis dua $\left(\mathrm{H}_{2}\right)$ menyatakan bahwa Person Organization Fit berpengaruh signifikan terhadap Organizational Citizenship Behavior (OCB). Koefisien jalur yang bertanda positif sebesar 1,342 dengan nilai C.R. sebesar 8,124 lebih besar dari 1,96, dan nilai probabilitas sebesar $* * *<\alpha$ sebesar 5\%, artinya Person Organization Fit berpengaruh sangat signifikan terhadap Organizational Citizenship Behavior (OCB).

Jadi hipotesis dua $\left(\mathrm{H}_{2}\right)$ diterima, artinya Person Organization Fit berpengaruh signifikan terhadap Organizational Citizenship Behavior (OCB).

3. Hipotesis tiga $\left(\mathrm{H}_{3}\right)$ menyatakan bahwa Person Job Fit berpengaruh terhadap Kinerja Karyawan. Koefisien jalur yang bertanda positif sebesar 0,020 dengan nilai C.R. sebesar 0,162 lebih kecil dari 1,96, dan nilai probabilitas sebesar $0,872>\alpha$ sebesar $5 \%$, artinya Person Job Fit tidak berpengaruh signifikan terhadap Kinerja Karyawan.

Jadi hipotesis tiga $\left(\mathrm{H}_{3}\right)$ ditolak, artinya Person Job Fit tidak berpengaruh secara signifikan terhadap Organizational Citizenship Behavior (OCB).

4. Hipotesis empat $\left(\mathrm{H}_{4}\right)$ menyatakan bahwa Person Organization Fit berpengaruh terhadap kinerja karyawan. Koefisien jalur yang bertanda positif sebesar 0,421 dengan nilai C.R. sebesar 5,799 lebih besar dari 1,96, dan nilai probabilitas sebesar $* * *<\alpha$ sebesar 5\%, artinya Person Organization Fit berpengaruh signifikan terhadap kinerja karyawan.

Jadi hipotesis empat $\left(\mathrm{H}_{4}\right)$ diterima, artinya Person Organization Fit berpengaruh signifikan terhadap Kinerja Karyawan.

5. Hipotesis lima $\left(\mathrm{H}_{5}\right)$ menyatakan bahwa Organizational Citizenship Behavior (OCB) berpengaruh terhadap Kinerja Karyawan. Koefisien jalur yang bertanda positif sebesar 0,381 dengan nilai C.R. sebesar 5,348 lebih besar dari 1,96, dan nilai probabilitas sebesar *** $<\alpha$ sebesar 5\%, artinya Organizational Citizenship Behavior (OCB) berpengaruh terhadap Kinerja Karyawan.

Jadi hipotesis lima $\left(\mathrm{H}_{5}\right)$ diterima, artinya Organizational Citizenship Behavior (OCB) berpengaruh secara signifikan terhadap Kinerja Karyawan.
Penelitian yang dilakukan pada subjek Karyawan Universitas Islam Kalimantan Muhammad Arsyad Al Banjari Banjarmasin, ditemukan bahwa person job fit yang merupakan kesesuaian karakteristik individu dengan pekerjaan berpengaruh tidak signifikan terhadap Organizational Citizenship Behavior (OCB), dan juga berpengaruh tidak signifikan terhadap Kinerja Karyawan. Dari hasil temuan di Penelitian ini diketahui bahwa dalam hal perekrutan karyawan dilakukan belum sesuai prosedur pada manajemen sumber daya manusia dengan tahapan adanya analisis pekerjaan (jobs analysis), adanya gambaran pekerjaan (jobs description), adanya spesifikasi pekerjaan (jobs spesification), dan adanya penilaian berupa hasil pekerjaan (jobs evaluation). Dalam hal penerapan spesifikasi pekerjaan, seringkali terabaikan, karena dalam perekrutan karyawan masih lemah dalam penerapan kompetensi dan ijazah yang disyaratkan penempatan posisi karyawan tersebut.

\section{CONCLUSION}

1).Persepsi tentang person job fit terhadap organizational citizenship behavior karyawan Universitas Islam Kalimantan Muhammad Arsyad Al Banjari Banjarmasin, nilainya sangat kecil, Sehingga hal ini diabaikan atau dapat dinyatakan bahwa, person job fit tidak signifikan dan tidak berpengaruh terhadap organizational citizenship behavior pada karyawan Universitas Islam Kalimantan Muhammad Arsyad Al Banjari Banjarmasin.

2). Persepsi person organization fit berpengaruh positif secara signifikan terhadap organizational citizenship behavior, karena telah teruji kebenarannya. Jika persepsi tentang person organization fit terhadap organizational citizenship behavior diterapkan dengan baik pada karyawan Universitas Islam Kalimantan Muhammad Arsyad Al Banjari Banjarmasin, maka organizational citizenship behavior ini akan semakin baik pula atau fit.

3). Persepsi tentang Person Job Fit terhadap Kinerja Karyawan, ternyata tidak dapat diterima atau ditolak, karena belum teruji kebenarannya. Hal ini memberi makna bahwa, persepsi tentang person job fit terhadap kinerja karyawan Universitas Islam Kalimantan Muhammad Arsyad Al Banjari Banjarmasin, ialah belum baik atau belum fit. karena sangat kecil, dan kinerja karyawan sangat besar dipengaruhi faktor lain.

4). Persepsi person organization fit berpengaruh positif secara signifikan terhadap kinerja karyawan, karena telah teruji kebenarannya. Jika persepsi tentang person organization fit terhadap kinerja karyawan diterapkan dengan 
baik pada karyawan Universitas Islam Kalimantan Muhammad Arsyad Al Banjari Banjarmasin, maka kinerja karyawan ini akan semakin baik pula atau fit.

5). Persepsi organizational citizenship behavior berpengaruh secara signifikan terhadap kinerja karyawan Universitas Islam Kalimantan Muhammad Arsyad Al Banjari Banjarmasin, karena telah teruji kebenarannya. Hal ini memberi makna, jika persepsi tentang organizational citizenship behavior diterapkan dengan baik, maka kinerja karyawan semakin baik pula.

\section{SUGGESTIONS}

Saran pada Pemilik selaku Pembina yakni ; Badan Pengurus Yayasan Uniska MAB Banjarmasin, melimpahkan sebagian authority nya, khususnya seleksi rekrutmen dan penempatan karyawan, di bawah jabatan Rektor dan Wakil Rektor, Dekan dan Wakil Dekan (seperti ; Direktur/ Asdir Pada Program Pascasarjana, Kepala Lembaga / Pusat, Biro, UPT., Bagian, Sub bagian., serta jabatan-jabatan lainnya diserahkan kepada Baperjakat (Badan Pertimbangan Jabatan dan Kepangkatan) Uniska MAB Banjarmasin c.q. Biro Kepegawaian, guna melaksanakan Job analysis, job description, job specification, dan job evaluation, sehingga pelaksanaan person job fit, dan person organization fit, dapat lebih dioptimalkan oleh pimpinan di Universitas Islam Kalimantan Muhammad Arsyad Al Banjari Banjarmasin.

\section{REFERENCES}

Arikunto, Suharsimi, 2003. Prosedur Penelitian Suatu Pendekatan Praktek, Edisi Revisi V, Rineka Cipta, Jakarta.

Barrick, R. Murray., and Mount, K. Michael. (2005). Yes, Personality Matters: Moving On To More Important Matters. Human performance, 18(4), 359- 372.

Bernarddin, H.John, dan Joyce E.A.Russel. 1995. Human Resource Management : An Experential Approach. Singapore: Mc. Graw Hill, Inc.

Bohlander, George., and Snell, Scott. 2004. Principles of Human Resource. Management, 15th ed. Mason, $\mathrm{OH}$ : South Western - Cengage Learning

Bowen, DE., Ledford, GE and Nathan,BR., 1997. Hiring for The Organization, Not The Job, Academy of Management Executive, Vol. 5., No. 5.
Bungin, Burhan, 2009. Metode Penelitian Kuantitatif, Kencana Prenada Media Group, Jakarta.

Dessler, Gary, 1997. Human Resource Management, 7th Edition, Prentice Hall, Inc.

Dessler, Gary, 2006. Human Resource Management (Manajemen Sumber Daya Manusia), Edisi ke 9 Jilid 2, Edisi Bahasa Indonesia, Indeks, Jakarta.

Edwards, P.J., and Bowen, P.A., 1991. Risk and Risk Management in Construction: A Review and Future Direction for Research, Engineering Construction and Architectural Management, Vol. 5, No. 4, pp. 339-349.

Ferdinand, Augusty, 2006. Metode Penelitian Manajemen: Pedoman Penelitian untuk Skripsi, Tesis dan Disertasi Ilmu Manajemen, Semarang: Badan Penerbit Universitas Diponegoro.

Ghozali, Imam, 2011. Aplikasi Analisis Multivariate Dengan Program SPSS, Semarang, UNDIP.

Gomes, Luis R. Meija ; David Balkin ; Robert L Candy, 2001. Managing Human Resources , Edition 3, Prentice Hall International., Inc. New York.

Hair, Joseph F., Raph E Anderson, Ronal L. Tatam, and William C. Black, 1998. Multivariate Analysis, Fifth Edition, Prentice Halll International Inc.

Handler, Charles, 2004. The Value of Person Organization Fit ere Networking, Prentice Hall International., Inc. New York.

Irawan, Prasetya, Suryani S.F.Motok, Sri Wahyu Krida Sakti, 1997. Manajemen Sumber Daya Manusia, Jakarta: STIA LAN Press.

Jahangir, Nadim, Akbar M.M, Haq, Mahmudul. 2004. Organizational Citizenship Behavior : Its Nature and Antecedents. BRAC University Journal, Vol. 1, No. 2, 75-85

Kristof, A.L., (1996). Person Organization Fit: an integrative review of its conceptualizations, measurement, and implication. Personnel Psychology 49. 149. 
Mathis, R.L., \& J.H. Jackson, 2006. Human Resource Management, Terjem. Diana Angelicia, Edisi 10, Thomson, Salemba Empat, Jakarta.

Mathis, Robert L dan Jackson, John H, 2004. Manajemen Sumber Daya Manusia, Buku ke dua. Salemba Empat. Jakarta

Nazir, Mohammad, 2002. Metode Penelitian, Cetakan Kelima, Ghalia, Jakarta.

Netemeyer, R.G.,Boles, S.B., McKee, D.O., 1999. An Investigation into The Antecedents or Organizational Citizenship Behaviors in a Personal Selling Conteext, Journal of Marketing., Vol. 61 : 85-98

Organ, Dennis,W., $1997 . \quad$ Organizational Citizenship Behavior: The Good Soldier Syndrome. Lexington, MA: Lexington Books.

O'Relly, C.A., Chatman, J.A.. \& Caldwell, D.F., 1991. People and Organizational Culture : A Profile Comparison Approach To Assessing Person Organization Fit. Academy of Management Journal, 34 (3) : 487-516.

Ozag D, Duguma B, 2005. The Relationship Between Cognitive Processes ad Perceived Usefulness: An Extension of The Technology Acceptance Model2, Working Paper. East Carolina University, http://vww.ecu.edu

Podsakoff, Philip M., MacKenzie, S.B., Paine, J.B., dan Bachrach, D.G., 2009. Organizational Citizenship Behavior: a Critical Review of Theoretical Empirical Literature and Suggestions for Future Research. Journal of Management, 26 (3): 513-563

Robbins, Stephen P., 2007. Perilaku Organisasi, Buku I, Edisi 12, Salemba Empat, Jakarta.
Ruky, A. 2006. Sumber Daya Manusia Berkualitas Mengubah Visi Menjadi Realitas. Cetakan Kedua. Jakarta: PT. Gramedia Pustaka Utama.

Sarwono, S. W., 2002. Teori-teori psikologi sosial. Jakarta: Raja Grafindo Persada.

Schneider, B., Goldstein, H.W., \& Smith, D.B., 1995. The ASA framework: an update. Personner Psychology, 48, 747-773.

Simamora, Henry, 2007. Manajemen Sumber Daya Manusia, Edisi III, STIE YKPN, Yogyakarta.

Sims, Randi L., and K. Galen Kroeck, 1994. The Influence of Ethical Fit on Employee Satisfaction, Commitment and Turnover, Journal of Business Ethics, 13 (December), 939-947.

Soedjono, 2005. Pengaruh Budaya Organisasi terhadap Kinerja Organisasi dan kepuasan Kerja Karyawan pada Terminal Penumpang Umum di Surabaya. Jurnal Manajemen dan kwirausahaan Vol. 7 No. 1. STIESIA Surabaya.

Sugiarto, 2001. Teknik Sampling. Penerbit PT Gramedia Pustaka Utama. Jakarta

Tabachnick, B. G., \& Fidell, L. S., 2007. Using multivariate statistics $5^{\text {th }}$ ed., Allyn and Bacon, Boston.

Vancouver,J.B., \& Schmitt, N.W., 1994. An Exploratory Examination of Person Organization Fit: Organization Goal Congruence. Personnel Psychology.

Valentine, S., Godkin, L., Lucero, M., 2002. Ethical Context, Organizational Commitment, and Person-Organization Fit. Journal of Bussiness Ethics, 41: 349-360 